\title{
PENGARUH BRAND IMAGE DAN KUALITAS PRODUK TERHADAP KEPUTUSAN PEMBELIAN SUSU CAIR DALAM KEMASAN SIAP MINUM MEREK ULTRA MILK DI KABUPATEN BADUNG (Studi Pada Konsumen Ultra Milk di Kabupaten Badung - Bali)
}

\author{
Debora Angelina Halawa, Luh Komang Candra Dewi \\ Sekolah Tinggi Ilmu Ekonomi Triatma Mulya, Badung - Bali \\ e-mail : deboraangelinahalawa@gmail.com
}

\begin{abstract}
Abstrak
Penelitian ini bertujuan untuk menganalisis apakah brand image dan kualitas produk berpengaruh secara parsial terhadap keputusan pembelian susu cair dalam kemasan siap minum merek Ultra Milk di Kabupaten Badung. Teknik pengumpulan data dalam penelitian ini yaitu dengan angket. Pengambilan sampel menggunakan metode purposive sampling, yaitu teknik pengambilan sampel yang dilakukan atas tujuan dan pertimbangan tertentu dengan kriteria konsumen yang sedang membeli susu Ultra Milk di warung, toko, atau swalayan yang ada di Kabupaten Badung dan usia konsumen minimal 17 tahun. Berdasarkan hasil penelitian, diperoleh persamaan regresi $Y=0,775+0,705 X 1+0,292 X 2$, yang artinya apabila brand image naik sebesar satu satuan, maka keputusan pembelian akan meningkat sebesar 0,705 satuan. Dan apabila kualitas produk naik sebesar satu satuan, maka keputusan pembelian akan meningkat sebesar 0,292 satuan. Pengujian hipotesis pertama menunjukkan hasil bahwa koefisien regresi $X_{1}\left(b_{1}\right): t_{\text {hitung }}(7,448)>t_{\text {tabel }}(1,661)$. Dan pengujian hipotesis kedua menunjukkan hasil bahwa koefisien regresi $X_{2}\left(b_{2}\right)$ : $t_{\text {hitung }}(4,477)>t_{\text {tabel }}(1,661)$. Hal ini berarti terdapat pengaruh positif dan signifikan secara parsial antara brand image dan kualitas produk terhadap keputusan pembelian susu cair dalam kemasan siap minum merek Ultra Milk di Kabupaten Badung. Implikasi bagi PT Ultrajaya Milk Industry \& Trading Company Tbk sebagai produsen Ultra Milk adalah agar senantiasa mempertahankan dan meningkatkan brand image serta kualitas produk sehingga keputusan pembelian konsumen dapat terjaga dengan baik, dan juga mengevaluasi kualitas produk yang memiliki pengaruh lebih kecil dibandingkan dengan brand image.
\end{abstract}

Kata Kunci: brand image, kualitas produk, keputusan pembelian.

\begin{abstract}
This study aims to analyze whether brand image and product quality partially influence the purchase decision of Ultra Milk as a brand of liquid and ready-to-drink milk category in Badung regency. Data collection technique in this study is through distributing the questionnaires. Sample selection uses purposive sampling method, which is sampling technique based on purpose and certain consideration with criteria as following: consumers who are buying Ultra Milk at the shop, store, or supermarket in Badung regency and consumer's age is at least 17 years old. Based on the research result, the regression equation is $Y=0,775+0,705 X 1+0,292 X 2$, which means if brand image increases by one unit, then purchase decision will increase by 0,705 unit. Meanwhile, if product quality increases by one unit, so purchase decision will increase by 0,292 unit as well. The first hypothesis test shows that regression coefficient $X_{1}\left(b_{1}\right): t_{\text {count }}(7,448)>t_{\text {table }}(1,661)$. And the second hypothesis test shows that regression coefficient $X_{2}\left(b_{2}\right)$ : $t_{\text {count }}(4,477)>t_{\text {table }}(1,661)$. It means there is positive and partially significant influence between brand image and product quality to purchase decision of Ultra Milk in Badung Regency. The implication for PT Ultrajaya Milk Industry \& Trading Company Tbk as manufacturer of Ultra Milk is in order to keep and improve both of brand image and product quality to maintain the purchase decision. Besides, the company must evaluate product quality which has lower influence if compared to brand image.
\end{abstract}

Keywords: brand image, product quality, purchase decision. 


\section{Pendahuluan}

Sebagai negara dengan jumlah penduduk lebih dari 250 juta jiwa, Indonesia menjadi lahan bisnis yang menguntungkan bagi para pelaku industri, salah satunya adalah industri makanan dan minuman. Hal tersebut dikarenakan industri ini bergerak dalam penyediaan kebutuhan pokok manusia, yaitu pangan. Berdasarkan data Badan Pusat Statistik (BPS) tahun 2011-2015, setiap tahunnya industri makanan dan minuman mengalami pertumbuhan yang pesat dan memiliki kontribusi terbesar terhadap Produk Domestik Bruto (PDB) Indonesia. Selain itu, berdasarkan data Kementrian Perindustrian Republik Indonesia, pada triwulan I tahun 2016 pertumbuhan industri makanan dan minuman mencapai 7,55\% dibandingkan periode sebelumnya. Hal ini menunjukkan semakin meningkatnya jumlah perusahaan yang beroperasi di Indonesia, dan otomatis menimbulkan persaingan yang ketat di antara para pelaku usaha karena banyaknya produk yang beredar.

Salah satu jenis produk yang ditawarkan di pasar adalah susu cair dalam kemasan siap minum. Berbeda dengan jenis produk susu lainnya seperti susu bubuk dan susu kental manis, susu cair dalam kemasan siap minum lebih praktis untuk dikonsumsi. Munculnya produk ini juga menjadi solusi bagi rendahnya konsumsi susu per kapita masyarakat Indonesia. Hadirnya susu cair dalam kemasan siap minum diharapkan dapat meningkatkan kesadaran masyarakat akan manfaat meminum susu. Salah satu merek susu cair dalam kemasan siap minum yang terkenal adalah Ultra Milk. Ultra Milk merupakan produk unggulan dari PT Ultrajaya Milk Industry \& Trading Company Tbk. Dalam proses produksinya, perusahaan menggunakan teknologi Ultra High Temperature (UHT) yang dikolaborasikan dengan teknologi pengemasan aseptik. Penggunaan teknologi UHT bertujuan untuk mengeliminasi bakteri patogen, menjaga kesegaran susu, serta menjaga kandungan nutrisi yang ada pada susu. Setelah proses produksi selesai, selanjutnya dikemas dalam kemasan aseptik untuk melindungi susu dari sinar ultra violet, udara, dan bakteri yang mungkin akan mengkontaminasi susu.

Sebagai produk susu yang pertama kali menggunakan teknologi tersebut di Indonesia, selama kurang lebih 40 tahun Ultra Milk mampu menjadi produk berkualitas yang tahan lama tanpa ada kerusakan dari luar sebelum dikonsumsi. Melihat peluang pasar yang besar, produsen lain memiliki inisiatif untuk meluncurkan produk sejenis. Bahkan beberapa produk lain juga menggunakan teknologi yang sama dengan Ultra Milk, yaitu UHT dan kemasan aseptik. Persaingan yang ketat di antara produsen susu secara tidak langsung mengharuskan PT Ultrajaya Milk Industry \& Trading Company Tbk untuk dapat menciptakan produk dengan citra yang kuat di masyarakat dan memiliki kualitas yang baik, sehingga dapat mendorong keputusan pembelian konsumen. Berikut adalah Tabel 1 yang menyajikan data rating produk susu cair dalam kemasan siap minum di Indonesia tahun 2012-2016 berdasarkan Top Brand Index.

TABEL 1

RATING SUSU CAIR DALAM KEMASAN SIAP MINUM DI INDONESIA

TAHUN 2012-2016

\begin{tabular}{cccccc}
\hline Merek & 2012 & 2013 & 2014 & 2015 & 2016 \\
\hline Ultra Milk & $30,7 \%$ & $32,7 \%$ & $36,4 \%$ & $36,1 \%$ & $44,1 \%$ \\
Frisian Flag & $26,8 \%$ & $23,7 \%$ & $15,8 \%$ & $15,6 \%$ & $23,0 \%$ \\
Indomilk & $21,4 \%$ & $22,5 \%$ & $18,0 \%$ & $21,6 \%$ & $19,0 \%$ \\
Milo & $6,5 \%$ & $6,2 \%$ & $9,1 \%$ & $8,1 \%$ & $3,3 \%$ \\
Bear Brand & $3,4 \%$ & $4,8 \%$ & $5,6 \%$ & $7,3 \%$ & $5,0 \%$ \\
Milkuat & $3,2 \%$ & $3,1 \%$ & $4,6 \%$ & $3,6 \%$ & - \\
\hline
\end{tabular}

Sumber : www.topbrand-award.com (2016) 
Pengukuran rating pada Tabel 1 didasarkan pada pangsa pasar yang dikuasai oleh sebuah merek. Maka dapat disimpulkan bahwa selama lima tahun berturut-turut Ultra Milk berhasil menjadi market leader susu cair dalam kemasan siap minum di Indonesia. Melihat pencapaian ini, dapat diindikasikan bahwa pihak perusahaan telah mampu mempertahankan keputusan pembelian konsumen terhadap produk Ultra Milk.

Sebelum memutuskan untuk membeli sebuah produk konsumen yang dihadapkan dengan berbagai alternatif pilihan akan mengevaluasi apakah produk yang hendak dibelinya sesuai dengan kebutuhannya atau tidak. Hal ini tentunya dipengaruhi oleh persepsi masingmasing konsumen terhadap sebuah produk. Persepsi antara seseorang dengan orang lainnya bisa saja sama atau bahkan berbeda. Konsumen lebih tertarik untuk membeli Ultra Milk dibandingkan produk lainnya, padahal produk lain tersebut memiliki manfaat, tampilan, dan rasa yang relatif sama. Hal ini dapat terjadi karena ada sebuah anggapan yang positif terhadap merek Ultra Milk. Produsen dapat membentuk persepsi konsumen dengan berbagai macam cara, salah satunya adalah melalui brand image.

Selain brand image, kualitas produk merupakan hal penting yang perlu diperhatikan perusahaan guna mendorong keputusan pembelian konsumen. Semakin dapat memenuhi harapan konsumen, maka dapat dikatakan sebuah produk semakin berkualitas. Harapan atau ekspektasi konsumen terhadap produk yang satu dengan produk lainnya bisa saja berbeda, tergantung dari pengetahuan konsumen terhadap produk tersebut. Demikian pula halnya dengan ekspektasi terhadap susu cair dalam kemasan siap minum. Konsumen mengharapkan produk susu yang praktis, sehat, mudah didapat, dan memiliki varian rasa yang enak.

Kabupaten Badung merupakan salah satu kabupaten dari delapan kabupaten yang ada di Bali, yang terdiri dari enam kecamatan dan 64 desa. Kabupaten Badung menjadi daerah pusat pariwisata Pulau Dewata dikarenakan banyaknya objek wisata yang ditawarkan jika dibandingkan dengan kabupaten lainnya. Sebagai titik pusat pariwisata Bali, Kabupaten Badung banyak dikunjungi wisatawan asing. Kehadiran wisatawan asing ini membawa beberapa dampak bagi gaya hidup masyarakat Badung, salah satunya adalah gaya hidup yang serba instan dan praktis dalam berbagai hal. Dari waktu ke waktu, gaya hidup masyarakat mengalami perubahan yang dinamis. Perubahan tersebut dapat dilihat dari cara berpakaian, cara berkomunikasi, dan juga pola konsumsi masyarakat setempat. Dalam kaitannya dengan hal mengonsumsi sebuah produk, pola hidup masyarakat barat yang terbiasa mengonsumsi produk yang praktis secara tidak langsung mempengaruhi pola konsumsi masyarakat Badung. Kini, warga lebih gemar membeli produk yang praktis untuk dikonsumsi. Berbicara mengenai produk yang praktis, susu cair dalam kemasan siap minum merupakan salah satu di antaranya. Konsumen dapat membeli dan meminumnya di waktu dan tempat yang sama, karena susu tidak perlu diolah terlebih dahulu. Apalagi dengan khasiat susu yang baik bagi kesehatan, konsumen mendapatkan dua manfaat sekaligus, yakni praktis dan tentunya sehat.

Berdasarkan latar belakang masalah tersebut di atas, maka rumusan masalah dalam penelitian ini adalah: (1) Apakah brand image berpengaruh secara parsial terhadap keputusan pembelian susu cair dalam kemasan siap minum merek Ultra Milk di Kabupaten Badung? (2) Apakah kualitas produk berpengaruh secara parsial terhadap keputusan pembelian susu cair dalam kemasan siap minum merek Ultra Milk di Kabupaten Badung?

\section{Metode}

Penelitian ini merupakan penelitian yang bersifat menjelaskan atau explanatory research yang melibatkan konsumen susu cair dalam kemasan siap minum merek Ultra Milk di Kabupaten Badung yang berjumlah 100 orang. Dalam penelitian ini digunakan dua variabel, yakni variabel bebas dan variabel terikat. Di mana brand image sebagai variabel bebas pertama (X1) dan kualitas produk sebagai variabel bebas kedua (X2), sedangkan variabel terikat pada penelitian ini adalah keputusan pembelian $(Y)$. Jenis data yang digunakan ada dua, yaitu data kuantitatif dan data kualitatif. Sumber data yang penulis gunakan adalah data 
primer dan data sekunder. Prosedur pengumpulan data pada penelitian ini ialah melalui penyebaran angket, dokumentasi, dan juga melakukan wawancara terhadap responden. Keseluruhan jumlah angket pernyataan yang disebar adalah 100, dan diterima kembali dengan jumlah yang sama. Untuk mengolah dan menganalisis data digunakan software SPSS (Statistical Package for Social Science) versi 20.0 for Windows, dengan teknik analisis deskriptif kuantitatif, uji validitas dan reliabilitas data, uji asumsi klasik (uji normalitas data, uji multikolinearitas, dan uji heteroskedastisitas), uji regresi linier berganda, serta uji t.

\section{Hasil Dan Pembahasan}

Berdasarkan uji karakteristik responden yang telah dilakukan, dapat diketahui bahwa jumlah responden yang berjenis kelamin laki-laki dan perempuan adalah sama, yakni masingmasing sebanyak 50 orang atau $50 \%$. Jika ditinjau dari usia, responden yang berusia 17-25 tahun memiliki jumlah terbanyak yaitu 66 orang atau $66 \%$, usia $25-30$ tahun sebanyak 14 orang atau $14 \%$, dan responden dengan usia lebih dari 30 tahun sebanyak 20 orang atau $20 \%$. Sedangkan apabila dilihat dari segi pekerjaan, sebagian responden penelitian berprofesi sebagai mahasiswa yakni sebanyak 52 orang atau $52 \%$, wiraswasta sebanyak 26 orang atau $26 \%$, dan pegawai sebanyak 22 orang atau $22 \%$. Hasil uji validitas menunjukkan bahwa 15 item pernyataan yang diajukan kepada responden melalui angket dinyatakan valid. Hal ini dapat dilihat dari nilai korelasi setiap item pernyataan yang bernilai positif dan besarnya lebih dari 0,3. Dari hasil uji reliabilitas dapat diketahui bahwa nilai koefisien Cronbach's Alpha dari seluruh variabel penelitian lebih dari 0,60 sehingga dapat dikatakan semua konsep pengukur masing-masing variabel dalam angket reliable. Hal tersebut berarti alat ukur yang digunakan pada penelitian ini dapat diandalkan. Berdasarkan uji normalitas yang dilakukan, dapat diketahui bahwa nilai Asymp. Sig variabel brand image, kualitas produk, dan keputusan pembelian sudah lebih besar dari 0,05 yaitu 0,275, 0,064 dan 0,330. Hal tersebut berarti distribusi data pada penelitian ini adalah normal. Alat uji asumsi klasik yang kedua adalah uji multikolinearitas. Hasil pengujian menunjukkan bahwa nilai tolerance kedua variabel bebas yakni brand image dan keputusan pembelian lebih dari $10 \%$ atau 0,1 yaitu sebesar 0,878 . Dan nilai VIF kedua variabel bebas kurang dari 10 yaitu sebesar 1,139 . Hal ini berarti tidak terjadi multikolinearitas. Dan uji terakhir dari asumsi klasik ialah uji heteroskedastisitas. Dari gambar scatterplot yang diperoleh, dapat dilihat bahwa titik-titik tidak membentuk suatu pola yang jelas dan menyebar di atas dan di bawah angka 0 pada sumbu $Y$, sehingga dapat disimpulkan bahwa tidak terjadi heteroskedastisitas. Dari analisis regresi linier yang telah dilakukan, diperoleh persamaan $Y=0,775+0,705 X 1+0,292 X 2$. 0,775 adalah konstanta, yang berarti apabila brand image dan kualitas produk diasumsikan tidak ada, maka keputusan pembelian akan bernilai positif sebesar 0,775 . Sedangkan koefisien regresi variabel bebas pertama yaitu 0,705 memiliki arti bahwa jika brand image (X1) naik sebesar satu satuan, maka keputusan pembelian $(Y)$ akan meningkat sebesar 0,705 satuan. Demikian pula halnya dengan koefisien regresi variabel bebas kedua yaitu 0,292 berarti bahwa jika kualitas produk (X2) naik sebesar satu satuan, maka keputusan pembelian (Y) akan meningkat pula sebesar 0,292 satuan. Berdasarkan pengolahan data yang telah dilakukan pada penelitian ini, ditemukan bahwa seluruh hipotesis dapat dibuktikan sebagai berikut:

a. Koefisien regresi brand image $X 1=0,705$ positif, dengan thitung $=7,448$ lebih besar dari ttabel $=1,661$ dan sig.t $=0,000(<0,05)$.

b. Koefisien regresi kualitas produk $X 2=0,292$ positif, dengan thitung $=4,477$ lebih besar dari ttabel $=1,661$ dan sig.t $=0,000(<0,05)$.

Hasil tersebut memberikan gambaran bahwa brand image dan kualitas produk berpengaruh secara positif dan signifikan secara parsial terhadap keputusan pembelian susu cair dalam kemasan siap minum merek Ultra Milk di Kabupaten Badung. 


\section{Simpulan dan Saran}

Dari hasil analisis diperoleh bahwa nilai koefisien regresi kedua variabel bebas bernilai positif serta nilai thitung kedua variabel bebas lebih besar dari nilai ttabel dengan sig.t $=0,000$ $(<0,05)$, sehingga hipotesis nol $(\mathrm{H} 0)$ ditolak dan menerima hipotesis alternatif $(\mathrm{Ha})$. Dengan demikian maka dapat disimpulkan bahwa terdapat pengaruh positif dan signifikan secara parsial antara brand image dan kualitas produk terhadap keputusan pembelian, sehingga apabila brand image dan kualitas produk semakin baik maka keputusan pembelian susu cair dalam kemasan siap minum merek Ultra Milk di Kabupaten Badung juga akan semakin meningkat.

Berdasarkan kesimpulan yang telah diperoleh, maka berikut merupakan saran-saran sebagai pelengkap hasil penelitian: (1) Brand image dan kualitas produk memiliki kontribusi yang cukup besar terhadap keputusan pembelian susu cair dalam kemasan siap minum merek Ultra Milk di Kabupaten Badung, yaitu sebesar 53,7\%. Oleh karena itu, sebaiknya PT Ultrajaya Milk Industry \& Trading Company Tbk sebagai produsen Ultra Milk senantiasa mempertahankan dan meningkatkan brand image serta kualitas produknya sehingga keputusan pembelian konsumen dapat terjaga dengan baik. (2) Kualitas produk memiliki pengaruh yang lebih kecil dari pada brand image terhadap keputusan pembelian susu cair dalam kemasan siap minum merek Ultra Milk di Kabupaten Badung. Melihat hal ini, disarankan kepada PT Ultrajaya Milk Industry \& Trading Company Tbk untuk melakukan evaluasi terhadap kualitas produknya. Selain itu perusahaan juga harus terus berusaha meningkatkan kualitas produk Ultra Milk dengan cara mempertahankan ciri khas rasa, mendesain kemasan produk yang praktis bagi konsumen, menciptakan varian rasa susu yang baru, berkomitmen untuk memproduksi susu cair yang memiliki daya tahan yang baik, serta menjaga kualitas produk sehingga Ultra Milk aman untuk dikonsumsi. Apabila perusahaan telah berhasil untuk meningkatkan kualitas produk Ultra Milk, maka keputusan pembelian konsumen akan meningkat pula.

\section{Daftar Rujukan}

Algifari. Analisis Regresi. Edisi Kedua. Yogyakarta: BPFE.

Ghozali, Imam. 2006. Aplikasi Analisis Multivariate dengan Program SPSS. Semarang: Badan Penerbit Universitas Diponegoro Semarang.

Gunawan, Hendra. 2012. PT Ultrajaya Kuasai Pasar Susu Cair di Indonesia. m.tribunnews.com/bisnis/2012/12/06/ultrajaya-kuasai-pasar-susu-cair. Diakses pada 24 November 2016 pk.19.00 WITA.

Kotler dan Keller. 2009. Manajemen Pemasaran. Edisi Ke-12 Jilid 1\&2. Jakarta: PT. Indeks Kelompok Gramedia.

Kotler, Philip. 2013. Manajemen Pemasaran. Jilid 1. Jakarta: PT. Indeks Kelompok Gramedia.

PT. Ultrajaya Milk Industry Tbk. 2016. Selamat Datang di PT. Ultrajaya. www.ultrajaya.co.id. Diakses pada 24 November 2016 pk.15.00 WITA.

Setiadi, Nugroho J. 2010. Edisi Revisi: Perilaku Konsumen. Bandung: Kencana Prenada Media Group. 
Setiyono, Ivonne Veronica. 2014. Analisis Pengaruh Kualitas Produk, Harga, dan Brand Image Terhadap Keputusan Pembelian Mobil Honda Jazz. Skripsi Universitas Katolik Soegijapranata. Semarang.

Sugiyono. 2013. Metode Penelitian Manajemen. Yogyakarta: CV. Alfabeta.

Sulistyawati, Praba. 2011. Analisis Pengaruh Citra Merek dan Kualitas Produk Terhadap Keputusan Pembelian Laptop Merek Acer di Kota Semarang. Jurnal Fakultas Ekonomi Manajemen Universitas Diponegoro Semarang.

Supriyadi, dkk. 2016. Pengaruh Kualitas Produk dan Brand Image Terhadap Keputusan Pembelian (Studi Pada Mahasiswa Penguuna Produk Sepatu Merek Converse di Fisip Universitas Merdeka Malang. Jurnal Bisnis dan Manajemen Fakultas IImu Sosial dan IImu Politik Universitas Merdeka Malang.

Suryani, Ni Putu Diah Noviari. 2016. Brand Image dan Kualitas Produk Terhadap Keputusan Pembelian Mie Instant Supermie di Kota Madya Denpasar. Skripsi Sekolah Tinggi IImu Ekonomi Triatma Mulya. Bali.

Tjiptono, Fandy. 2008. Brand Mangement and Strategy. Yogyakarta: Andi Offset.

Top Brand Index. www.topbrand-award.com. Diakses pada 24 Novemeber 2016 pk.14.00 WITA.

Virawan, Wayan Adi. 2013. Pengaruh Harga, Kualitas Produk, dan Citra Merek Terhadap Keputusan Pembelian (Studi Pada Mahasiswa Fakultas Ekonomi Universitas Negeri Yogyakarta Pengguna Helm Merek INK). Skripsi Universitas Negeri Yogyakarta. 